\title{
Religious-Social Shaping of Technology Approach to Internet Use by an Urban Islamic Group in Indonesia
}

\author{
BINTAN HUMEIRA \\ BILLY SARWONO \\ Universitas Indonesia, Indonesia
}

\begin{abstract}
The perspective of religious groups about the internet in general can be arranged into two dichotomous categories, first, religious groups see the internet as something that must be rejected because it is identical with modernity that tends to be secular; second, is the opposite, that internet technology can be accepted by religious groups to support their various religious goals. Through the Religious-Social Shaping of Technology approach, this article observes that religious groups use and negotiate with technology for their religious purposes. This study applies a qualitative approach with in-depth interviews with administrators and members of religious groups. Based on the use of the internet by the Majelis Rasulullah, an urban Islamic group in Indonesia, this article discovers that the principles and values of group beliefs, as well as the group's goals and discourse about the internet influence the group's decision to accept the internet as part of group activities. In addition, this article also shows that internet use by religious groups has succeeded in changing group communication between group leaders and members from predominantly one-way and very limited into an interactive one. In addition, through internet use, the group has succeeded in building an online transaction system, showing that religious groups are no longer merely a religious discussion forum, but also a business entity. This article significantly enriches the study of internet use by religious groups in the Indonesian context.
\end{abstract}

Keywords: Technology, Internet, religious, group, religious-social shaping of technology.

\section{INTRODUCTION}

Interaction between religious groups and the internet is not simple. There are religious groups who reject internet use in their religious practices. However, some groups see the internet as a way to achieve their goal of spreading religious messages. The groups who reject internet use consider the internet vulnerable to contents considered immoral and contradicting religious dogma. The ease offered by the internet for users to access and produce a variety of content, especially pornography, crime, and secularism, induces religious groups, mainly traditional or orthodox ones, to choose to avoid the internet in their religious practices. Orthodox groups understand that the internet will render the group members vulnerable to sin and disturb the order of group values.

On the other hand, the religious groups accepting the internet as part of group activities consider the internet as a space that offers easy access for anyone to search for a variety of content, including religious content. They consider the internet as a new way for religious groups to spread God's message and reach more followers. As a simulation, approximately 23 million of 132.7 million internet users in Indonesia visited religious sites in 2017 (APJII, 2017). Similarly, an article in New York Times.com by Preston (2011) shows that more than 43 million Facebook users are fans of at least one religious account. It indicates an increasing number of Facebook users who actively participate in online religious discussions. One example of popular online religious accounts is Jesus Daily, having more 
than 8 million followers and involving an average of 3 million users per week in online religious discussion activities.

The availability of the internet for individuals and religious groups opens new spaces not only for consumption, but also for the production of religious content. Some examples of the involvement of religious groups in the production of religious content on the internet are the emergence of religious service sites, such as GodTube or YouTube in the Christian version, e-vangelism, cyber-church, and cyber-temple. It appears that the internet technology plays an important role for religious groups to widely spread religious practices to their followers in daily life (Campbell, 2013). The internet is a tool to not merely expand offline religious activities in cyberspace, but also change existing religious activities to some extent. Individuals or members of religious groups no longer need to be present at church to listen to homilies or make confessions, or be present in the study room to study the Koran. They only need to visit religious service sites to fulfil their needs for worship.

In many situations, the presence of online service sites does not necessarily replace religious practices in the offline space. Religious practices in the offline space act as a source of knowledge for online religious practices and strengthen the offline practices (Campbell, 2005; Martinez-Zarate et al., 2008). Some churches that carry out offline religious rituals also open online sites that provide worship material or religious information that they convey in offline activities. Some Islamic groups continue to hold religious activities in the offline space such as recitation, Koran study, humming praise, as well as upload all study materials and videos to the Internet. Streaming religious shows aims to facilitate group members to be connected with religious activities even though they are not present. Through live broadcasts on the internet, group members are able to present a holy atmosphere in a different space. Thus, the existence of the internet strengthens offline religious rituals. It appears that the boundaries between online and offline realities are increasingly vague, challenging religious institutions to be able to maintain control over online practices (Barker, 2005). Studies in the mid and late 90s observed how the internet provided space for religious practices in cyberspace and ultimately transformed religious practices in many ways.

The increasing use of the internet for religious purposes is also shown by the Pew Research Center (2014), discovering that one of five Americans shares their beliefs online. The study by Pew on 3,217 people in 2014 finds that $20 \%$ respondents share their beliefs or religion through online social networks such as Facebook and Twitter, while 46\% respondents obtain religious content from online sources. Other findings indicate that respondents utilize online channels to share or search for religious content as a complement to, rather than replace, offline religious activities. This condition encourages religious communities to enter the online realm to spread religious content more broadly, as well as reach more worshipers.

In Indonesia, religious groups that actively use the Internet are religious groups in urban areas. These groups acknowledge that internet use is a part of daily life. One of the religious groups in urban areas in Indonesia, the Majelis Rasulullah, decides to accept the internet as part of their religious practice. The focus of the activities of this group is the teaching of Islam, and its membership is open and voluntary. This group routinely organizes recitation activities in mosques or open areas, with thousands of worshipers. The Majelis Rasulullah is led by a Habib, a term for religious leaders considered the descendants of the Prophet Muhammad. As an Islamic group that starts with linear and face-to-face religious learning activities, the presence of the internet becomes a new space in the group practice. 
This situation raises the question of how the Majelis Rasulullah deals with the presence of the internet as part of group religious activities. Thus, this article aims to observe how the Majelis Rasulullah, as an urban Islamic group, uses internet as part of group activities for religious purposes and its implications for group life.

\section{LITERATURE REVIEW}

There are two different perspectives of studies on the interaction of religious groups and the internet, namely first, observing religious groups rejecting internet use, and second, observing religious groups accepting the internet as part of group social practices. Several studies have shown the opposition of religious groups to internet technology because they consider the internet to damage religious values, threaten the social order of the groups, and show contents that alienate individuals from religion (Stout, 2012; Horowitz, 2000; Ben Shahar, 2009). Traditional religious groups regard religion as anti-technology and see technology as a representation of modernity that is synonymous with secular life. In traditional (orthodox) religious groups, the internet is considered dangerous and prone to sin (Campbell, 2007). A study on an Orthodox Jewish group revealing that they do not want to use the internet as part of a group. Similarly, the Amish group decides to avoid worldly life that can disrupt group values, including internet use. The refusal of religious groups to internet use is also related to the distribution of potentially dangerous contradictory content that negatively impacts the credibility of institutions and religious leadership (Meyrowitz, 1985). Even in online chat, the critical attitude of followers towards the belief system has eroded the credibility and authority of Buddhist priests in Japan. This finding also predicts that horizontal interaction will become more important in increasing the religious understanding of followers than the vertical delivery of religious doctrines from religious leaders to followers (Fukamizu, 2007)

One of the studies of the acceptance of the internet by religious groups shows how Evangelical groups use radio and television (Televangelism) for their religious activities. Furthermore, this group enters the internet space by creating an e-vangelims site. In addition, online church services have begun to emerge, and online meditation and online lectures are a new form of religious practices in the internet. These studies show that through media technology and the internet, religious groups spread their religious practices to the public (Campbell, 2013). Furthermore, studies on the correlation between religion and the internet in several religious groups in Australia and many Muslims in South Asia show that religious groups use the internet to help their worship and provide religious information, including lifestyle information (Mishra \& Semaan, 2010). Also, online space becomes a space for discussion of personal issues such as sexuality issues that are difficult to discuss in offline religious discussions (Marcotte, 2014), and sources of knowledge for religious practices in the offline space (Campbell, 2005; Martinez-Zarate et al., 2008). Even other studies show that religious groups use the internet to complement their religious practices in the offline space. Thus, it appears that the line between online and offline religious practices is blurred (Haythornthwaite \& Wellamn, 2002; Bakardijeva, 2003; Katz \& Rice, 2002).

More frequently, several previous studies on the interaction between religious groups and the internet describe the non-Asian context. There are merely few studies on the interaction between religious groups and the internet in the Indonesian context. This article wants to fill a research gap on the relation between religion and the internet in an 
Indonesian context that is unique in religious practice because of cultural influences. One of the studies on the interaction between religious groups and technology in Indonesia focuses on the acceptance of technology by Sunni Islamic groups in Indonesia (Bakti, 2018). This study explains how Sunni Islamic groups in Indonesia develops Radio and TV to provide teachings about Islam through Koran learning as well as monologues and dialogues discussing 'aqida (faith), sharia (law), and 'ahlaq (morality). This study also shows that the involvement of religious groups in using technology has succeeded in building the discourse of civil society development. Bakti also observes broadcast media use by Indonesian religious group, while this article emphasizes the internet use based on group values, traditions, and discourse.

The issue of correlation between religion and the internet came to the attention of experts at the first international conference on religion in the digital environment in 2001 at the University of Copenhagen, Denmark. This forum notices the rapid increase in the study of religion in the online space. Attention to studies on online religious not only practices observes the influence of technology in changing religion but builds a framework for explaining online religious activities in a broader socio-cultural context. In this regard, the focus of studies on online religious is directed not only at describing what happens when religion appears online but also explaining why this arises and its implications for the overall religious tradition. It follows the perspective of the Social Construction of Technology (SCOT) that pays attention to the interactions between individuals and technology and rejects the view of technological determinism that perceives technology as the cause of social change considered separate from human activity. Society is considered passive and only acts as an adopter. There is no technological development without human involvement using science to solve problems or achieve desired goals.

This article observes that group values and needs influence the correlation between religious groups and technology. This view is in line with the perspective of the Social Construction of Technology (SCOT) that considers humans to use technology actively according to their needs. Humans always do construction on technology, and therefore, technology develops. Individuals have a mindset in understanding technology that has implications for their actions on technology. Humans build interaction with technology through their interpretation of technology. Therefore, individuals have the potential to innovate or modify technology by referring to personal or group needs and values. Thus, technology is no longer seen as a tool or a machine, but as a system that involves aspects of values, traditions, and human habits in its use (Pacey, 2000). The practice of technology is closely related to the cultural system where technology develops because human interaction and technology become integrated activities in human life. Referring to the technical aspect, technology has similar function wherever they are present, but will differ in its use because it is related to the values and culture of its users. The values that also determine human interaction with internet technology are religious beliefs. The internet becomes a new space in religious practice that has so far been limited to worship spaces such as mosques, churches, and monasteries. Campbell (2010) defines it as the spiritualizing internet, namely a process of how individuals engage with internet technology for religious purposes. The internet has become a suitable space for users to engage in religious discourse and build a spiritual life.

This article employs the Religious-Social Shaping of Technology (RSST) approach that Campbell (2005) offers to observe how individuals or religious groups reject, accept or negotiate the use of technology related to moral code, values, beliefs, and traditions of the 
groups. RSST approach refers to the perspective of Social Shaping of Technology (SST), observing the process of interaction between human and technology as a form of individual negotiation of technology in daily life. This view opposes the view of technological determinism, stating that technology determines human life. SST explains that there are social processes that occur in the interaction between human and technology that encourage the emergence of technological innovation according to their needs. A study by Diane Zimmerman-Umble (year??, reference) on the Amish group shows that the group negotiates the technology of cell phones instead of rejecting it, using them as a shared, not personal, medium. Mobile phones are placed in public spaces and used by all group members. Mobile phones are also used by groups while maintaining distance from the secular world. This study shows that the process of using and modifying technology by religious groups is related to their ultimate goal and unique way of maintaining the social order of the group that supports group values and doctrines. Guzek (2015) shows a similar result in a study of the use of Twitter by Pope Francis. This study was conducted on 135 tweets by Pope Francis in 2014 for six months. The results show that Pope Francis understands Twitter as a medium to spread God's revelations and sacred Catholic missions, as well as emphasizing the Pope's position as God's representative in Vatican.

According to Campbell (2005), the Religious-Social Shaping of Technology (RSST) approach focuses on how religious groups negotiate the use of technology related to group religious values and traditions. This approach assumes that users choose technology based on not only the quality, but also their social construction of technology. This approach sees that the belief system and the meaning perceived by individuals or groups regarding technology affect how they choose and use technology in certain social situations. In addition to the belief system, historical factors and group background also determine the group negotiation process in the use of technology. In other words, it is necessary to examine the historical roots and traditions of the group to understand how the negotiation process takes place. There are moral codes, beliefs, and values held by groups when engaging themselves with internet technology, including language and discourse that frames the adoption and negotiation process. In this article, the RSST approach helps explain how religious groups understand the internet from a group perspective and ultimately influence their acceptance of the technology. According to the RSST perspective, the process of group acceptance of technology can be analyzed based on four aspects, namely: 1 ) history and tradition, 2) beliefs and basic patterns (core beliefs and patterns), 3 ) negotiation processes, and 4) framing and group discourse.

Historical and tradition aspects refer to how the history and traditions of groups form the standard of acceptance of the technology. The historical element observes previous group decisions and policies that influence the response to technology. Furthermore, this aspect also observes group learning that refers to sacred verses and religious practices that shape the interpretation of the group on technology. The aspect of faith refers to the social and religious values that are dominant in the groups that influence decision making on the use of technology and how groups interact in the online space. The next aspect - negotiation - refers to how religious groups decide and use strategies to accept, reject, or reconstruct technology according to the group values and needs. The negotiation process involves evaluating, identifying, and rejecting the negative impacts that may accompany technology. On one side, humans need technology, but on the other hand, it is often not in harmony with group values. This process can lead to the reconstruction of 
technology by generating an innovation. Reconstruction is a process that involves making choices about how technology can be accepted, in what context it is used, how it should be used, and in what aspects modification is needed (Campbell, 2010, p. 55). The last aspect is the aspect of framing and group discourse, referring to the discourse or frame used by the group in interpreting technology. Framing discourse refers to a set of group values and beliefs that guide the entire group life, including the use of technology. In framing group discourse about the internet, group views and personal views are two important aspects to observe, supposing there is a discourse that dominates the group's perspective in seeing the relationship of the group with technology, and how the discourse determines group decisions in the use of technology.

\section{METHODOLOGY}

This study applies a qualitative approach with a constructivist paradigm to understand how religious groups accept and negotiate the use of internet technology concerning aspects of values, traditions, history and group discourse, and implications for the groups. This article finds meaning and experience built by groups based on the perspectives of members and administrators as participants related to internet use in religious activities. According to Creswell (2003, p. 18), a qualitative approach is an approach to build knowledge based on a constructive perspective, such as finding meaning derived from individual experience, social and historical values to build a particular theory or pattern, or based on a participatory perspective or both. A qualitative study also aims to understand objects in depth (ideographic), not to find laws and make generalizations (Lincoln \& Guba, 1982). The data were collected using in-depth interviews with group members and administrators. The characteristics of informants are members of the group Majelis Rasulullah for a sufficiently long period, or more than four years. The assumption is that the involvement of members for more than four years enable them to understand the values, principles, and ways of group interaction, especially related to internet use as part of group religious practice. This study selected an Islamic group in Jakarta that involve themselves in an online environment through internet use, namely the Majelis Ta'lim Rasulullah. Majelis Ta'lim is a religious study group that emerges since the initial period when Islam entering Java. The process of studying religion in Majelis was initially carried out by Wali Songo when spreading Islam to the Javanese. This group conducts a linear learning process, face-to-face between the teacher and the worshipers. The activity of the group consists of reciting Koran, learning Hadith, and singing prayers of praise to the Prophet Muhammad.

\section{RESULT AND DISCUSSION}

This article explains the acceptance of internet technology by the Majelis Rasulullah in three parts, namely the practice of using the internet by the Majelis Rasulullah, the aspects that underlie the acceptance of internet technology, and the implications of internet use for groups. The results show that the practice of using the internet by the Majelis began in 2005 by creating a website www.majelisrasulullah.org. The following year, the Majelis expanded its involvement in the online world by using social media Facebook, Twitter, and Instagram. Establishing the website aims to convey various information about the Majelis Rasulullah, such as vision, mission, history, coverage of group activities, study material, schedule of religious activities, and streaming live broadcast coverage of group study activities. In addition, the Majelis created social media accounts, such as the Majelis Rasulullah SAW Facebook account, the @Mjl_Rasulullah Twitter account, and the Majelis Rasulullah SAW 
official Instagram account, to build group interaction with worshipers and the wider community. The Majelis also created a YouTube account to upload videos of Habib's lectures and routine recitation of the group. Apart from being an interactive media between the Majelis and worshipers, the use of social media is also intended to reach new worshipers.

Internet use, providing wide-open access to information for group worshipers, does not necessarily make Majelis provides content entirely to everybody. There is control over content management. Habib, as the leader, directly manages information in online conversation forums on the website. Habib directly answers a variety of questions from pilgrims. There are no intermediaries or moderators who manage the content in the forum. Habib does not only package content in online forums, but also controls the content that may appear in online media groups with certain limits. It shows that control over the content in the internet space is a way for Majelis to maintain the social order of the group. There is a unity of views in the offline and online spaces that represents group views. In this case, the view of the group or the Majelis is still dominated by the authority of Habib as the leader. Habib is an extraordinary figure for worshipers since they are believed to be the descendants of the Prophet Muhammad, a role model for Muslims. Thus, the lectures conveyed by Habib both in offline and online forums are not ordinary information. They contain glory that brings goodness for the worshipers. It indicates the high authority of Habib in group life. Subsequent to the Habib's leadership, the Council of teachers at Majelis took control of the content.

In addition to websites and social media, the Majelis also develops digital applications, namely MRDa'wah and MRShop, available to be downloaded online on mobile phones. This application facilitates the group members to obtain lecture material, activity info, prayer schedules, and streaming shows of routine weekly recitation activities. Through this application, the Majelis develops group activities in the form of online business, namely selling group attributes such as jackets, hats, turbans, and several books and tomes. Moreover, through this application, the Majelis provides services for payment of electricity bills, telephone, purchase of goods in instalments, and shopping in collaboration with DOKU, a digital payment system (digital money). This application for online transaction is a way for the Majelis to raise funds from members for group needs. From the beginning, the Majelis leader has emphasized that the Majelis will not be involved in practical political interests or business interests with other parties. Habib declares to maintain the independence of the Majelis from the pressure of other groups. However, the Majelis opens relations with many parties to hold dialogues for the interests of the ummah and $d a^{\prime} w a h$.

Internet use by the Majelis Rasulullah shows how internet technology is a tool or a means of extending group religious activities in real space (offline) to the online territory. O'Leary and Brasher state that "Cyberspace as Sacred Space" is a phenomenon of the presence of religious rituals in online spaces (Consalvo \& Ess, 2011, p. 233). This phenomenon also shows how technology has become part of the religious activities of the community. A study by Mishra and Semaan (2010) shows that a number of South Asian Muslims in the United States use internet technology for religious purposes, such as studying the Koran, discovering the worship schedule and information about halal food, discussing personal issues with others in forums, and even making decisions about their lifestyle after accessing various opinions on the internet. 
The decision of Majelis involved in the online space is inseparable from the aspects of history, tradition, and group values, as well as group discourse about technology. Historically, the Majelis's interaction with the internet began in 2005, though that does not necessarily mean that they were anti-technology in the previous years. Habib, teachers, and members commonly use cellular telephones as a means of communication. The acceptance of media technology by the Majelis is also apparent from the openness of the group to receive domestic and foreign media coverage of their religious activities. One of them is the coverage of the Majelis's activities by the United States Wall Street Journal (WSJ) about the birth of the Prophet Muhammad in Jakarta in 2012 with the title "Moderate Islamic Preachers Gain Followers in Indonesia." The Wall Street Journal writes the Majelis leaders as moderate religious leaders, open in building relationships with many parties, and voicing religious teachings that are peaceful and tolerant of differences. The closeness of the Majelis to technology is not limited to being a medium of group communication with worshipers, but also a means of building relationships with outsiders for religious purposes.

One of the reasons why the Majelis decides to use the internet is the increase in the community participation in the Majelis. According to the board of the Majelis, there are more than 10 thousand people attend recitation every week, and even more than 100,000 people attend the anniversary of the Prophet Muhammad's birthday. Such high community participation in religious practices encourages the Majelis to provide access for the wider community to participate in online activities of the Majelis, especially for worshipers unable to directly attend the activities.

The goal of the Majelis to reach broad worshipers refers to the value of the group that sees an obligation for every Muslim to preach in the right way. This group value refers to the verse of the Quran, namely QS. Al-Nahl 125: "Call (man) to the path of your Lord with wisdom and good teaching." This verse is conveyed by Habib and the teachers continuously in every teaching activity to the congregation. The Majelis and the congregation understand this wisdom as openness to use various methods as a means of $d a^{\prime} w a h$, including the use of technology. The wisdom has become the tradition of the Majelis to preach in a polite and kind manner.

According to Majelis members, one of the beliefs that support group decisions using the internet is the habit of the Habib of repeatedly conveying hadith about the goodness of following Majelis activities. This belief also arises from the experience of some members who feel their lives are calmer and better after regularly attending the Majelis. Therefore, for worshipers, participating in the Majelis becomes essential because it will bring a good life. For this reason, the Majelis sees the internet as an essential means of providing easy access for worshipers who are far away or unable to attend the Majelis offline. They can access the live stream of Koran recitation. For the worshipers, streaming shows are able to present the feeling as if they are actually in the Majelis and taking part in the flow of prayers and verses read by Habib, teachers and thousands of worshipers. Thus, internet use is able to merge offline and online religious practices. The existence of the internet as the extension of the group, present in the online space of the community. It seems that the Majelis considers that religious practices are not anti-technology. Instead of refusing, the Majelis adopts the internet as a means capable of bringing people to the path of religion. It means that the notion that the internet creates tension between the context of offline and online is not entirely true. The online and offline contexts are more likely to merge into one rather than influence one another. Other studies show that the difference between offline 
and online spaces is increasingly blurred because the internet is increasingly integrated into everyday reality (Bakardijeva, 2011; Campbell \& Lovheim, 2011).

The belief that technology is a means of $d a$ 'wah encourages the Majelis to form an information technology management team in the organization. The formation of the team aims to handle all online media used by the group, both from the technical and content aspects. In fact, many young and active members of the Majelis are technologically literate. Furthermore, the scope of the Majelis activities covers not only Jakarta, but also almost all areas along the North Coast and the South Coast of Java, and even to Bali, Mataram, West Irian, Singapore, Johor, and Kuala Lumpur. Thus, internet use, such as online sites (web sites) and social media, strongly supports the group's sacred mission of spreading religious content and practices that are more accessible to many people in various regions.

The Majelis decides to use the internet by paying attention to the impact of the internet on the lives of groups. Habib and the teachers are concerned with the issue of content to maintain the order of group values as a religious group. Habib and the teachers realize that religious content was closely related to God's dogma and the hadith of the Prophet Muhammad as a guide to religious life. Misrepresentation of content will bring problems to the group. Since the beginning of the Majelis's establishment, Habib has dominantly determined the flow of information and content in the Majelis. The teachers manage the content of religious teaching under the supervision of Habib as the leader. The entire information in the online media is broadcast following the approval of Habib, even though there is an information technology team formulating content. Habib even moderates his online forums on the website. This activity has changed since Habib Munzir passed away in 2013. The management of teaching content and online forums are under the supervision of the teacher council.

Setting boundaries in uploading content in an online space is a way for Majelis to negotiate with technology to align with the group's goals. Control over technology is a significant concern for internet use to remain coherent to bring people to religious observance. Control over technology is not limited to monitoring content, but also continuously reminding worshipers in Majelis activities to safeguard God's values. However, the Majelis is unable to control internet use by the members in the private sphere. McQuail (2012) states that the internet provides individuals with more control over usage and content.

Group negotiations on technology do not merely determine whether they accept or reject or construct the technology. This article shows that the Majelis of Rasulullah construct the technology by building special applications aimed at the wider community and worshipers. This application is a tool that can increase the involvement of members with the Majelis, not only on religious activities, but also online transactions. The Majelis builds MRDakwah and MRShop digital applications in Google Play Store. The MRDakwah application facilitates members to obtain a variety of study materials, info on recitation activities, prayer schedules, and streaming recitation. The other application, MRShop, provides services to sell Majelis attributes online, such as jackets, hats, scarves, and VCD lectures. MRShop also offers online payment transaction services to meet daily needs such as electricity, telephone bill, telephone credit, and even daily shopping at minimart. Thus, the involvement of the Majelis in the construction of technology is aimed at supporting religious objectives as well as developing the Majelis that no longer focuses on religious teaching but also develops the organization as a business entity for group funding purposes. 
This article shows that the process of acceptance of technology by the Majelis Rasulullah is not only based on the history, traditions, values, and needs of the group, but also the group discourse that the leaders continually convey. The leader repeatedly emphasizes how to uphold the noble values of the teachings of the Prophet Muhammad, one of which conveys the teachings of the hadith that the things we do all depends on intention. Good or bad technology depends on the purpose of its use. In this context, the Majelis frames technology as a value-free means. The internet can bring benefits should it is used with the right purpose. This discourse underlies the Majelis' perspective on technology as a tool or means that can provide benefits to support the sacred mission of religion. The internet is a proponent of group activities in spreading religious practices in an online space rapidly.

This article also shows that the process of acceptance of the use of internet technology by the Majelis has implications for the communication between group leaders and worshipers, from previously one-way and face-to-face to interactive. Interactivity in the online space provides a new open space in the Majelis between leaders and worshipers. This condition was previously minimal. Online space is possible to be accessed by anyone who has an internet network. Thus, there is an opportunity for members to interact directly with the leaders and the board of teachers. It is challenging to do in the offline space because many people are present during the activity. Even people see Habib only from a distance. It is difficult for worshipers to greet Habib, whom they consider to be a figure of glory. Therefore, the members feel that their conversation with Habib in online forums brings a different religious experience. People believe that direct prayer and advice from Habib bring blessings, even though in online space. There seems to be a tendency for online religious practices to replace the limitations in offline space.

Another implication of internet use by the Majelis is the emergence of new demands in organizations to manage the group's information and communication systems professionally. This condition requires the Majelis to divide tasks into groups to manage information and group communication. Previously, information about the Majelis was dominantly formulated and decided by Habib with his authority as a leader. The flow of information is centralized in the figure of Habib. The presence of information technology teams in the organization lead to the division of roles within groups to manage information, no longer dominant in the figure of Habib as a leader.

The participation of the Majelis Rasulullah as a religious group in the use of digital media is closer to what Helland (2000) has stated as religion online rather than online religion, namely how religious practices in the offline space enter into the online space, in contrast to online religion that sees religious practices grow online and shape their communities in the online realm. The findings of this study also show what Hoover (2002) states that the relationship between the internet and religion is seen as "digitalization of religion," observing how digital technology or the internet forces religious groups to adapt and change ideas about religious traditions, authority, or authenticity. In other words, there is a real contribution of digital technology to religion, which in the context of the Majelis Rasulullah, is helping groups to invite people to religious practices.

The relationship between the internet and religion shows how digital technology builds and interprets religion in new ways. The phenomenon of digitizing religion appears as a situation of how digital technology as a means extends offline religious activities to the online space, and even changes existing religious practices. This article shows how the Majelis Rasulullah adopts the digital technology platform to open broad access for people 
involved in religious practices. Its implication is that changes in the religious practices that were previously limited to offline to online. Observed from the perspective of the Majelis, the acceptance of internet technology enables the Majelis to manage information in a modern way.

The interactive and participatory characteristics of the internet contribute to changes in communication practices in the Majelis. The emergence of dialogue forums on websites and social media has succeeded in bridging the relationship between Habib and his followers through interactive two-way communication instead of one-way and highly limited communication. Thus, the presence of an online forum on the website can overcome all the obstacles of space and time. The existence of online forums seems to erase the unity of space and time as a requirement for social practices or actions. Giddens (1984) call the phenomenon as "time-space distanciation." The appropriation of time and space is the locus that distinguishes modern society from non-modern society. In traditional societies, the way of life of groups is organized based on the unity of space and time.

\section{CONCLUSION}

Internet use by the Majelis Rasulullah as a religious group shows how religion is not antitechnology, but it instead becomes a value system that supports the use of technology in harmony with religious goals. Values, traditions, goals, and discourse developed by the Majelis Rasulullah as a religious group are related to the role of technology as a means of da'wah, affecting the acceptance of internet technology by the group. The group does not merely adopt the internet, but also negotiates with technology by establishing online applications according to the needs of groups spreading religious messages while developing the economic function of the organization, namely obtaining funding from the public.

This article supports the opinion by Geertz (Pals, 1996) that religion is a cultural system that controls how humans understand reality in their daily lives. In this case, religion becomes a value system that controls how religious groups accept and negotiate internet use within the bounds that fit religious goals. Thus, there is a harmonious relationship, rather than conflict, when religion interacts with the internet. The presence of the internet encourages religious practices in the offline and online spaces to merge. There is a correlation between offline religious practices and internet users' online behavior (Haythornthwaite \& Wellamn, 2002). Even Bakardijeva (2003) sees that individual internet usage patterns are often influenced by individual religious behavior in the offline realm. Individuals feel that their religious practices in the online space confirm their beliefs. In other words, the activity of individuals or religious groups using the internet is a complement to their religious practices in the offline space (Katz \& Rice, 2002).

Therefore, this article shows that religious groups in Indonesia see the internet as part of da'wah because it is not considered to be contrary to religion as long as it is useful for da'wah. This acceptance obtains the support of the group and all members because Habib legitimizes it as a leader whose members see having religious authority. In other words, group acceptance depends more on the authority of religious leaders than on the interpretation of the scriptures. However, this study has limitations because it is only carried out on one religious group in Indonesia. Thus, there remains a vast opportunity for further studies on religious groups that may have different leadership and traditions. 


\section{ACKNOWLEDGEMENT}

This research is supported by Hibah TADOK 2018 funded by DRPM Universitas Indonesia Number: 1290/UN2.R3.1/HKP.00.05/2018.

\section{BIODATA}

Bintan Humeira is a Ph.D. Candidate of Communication, Universitas Indonesia. Her research interests are media studies, new media, and religion online. Email: bintan103@gmail.com

Billy Sarwono is a Professor of Communication, Universitas Indonesia. Her research interest is gender, media studies, and environmental issues. Email: billysarwono@gmail.com 


\section{REFERENCES}

Asosiasi Penyelenggaran Jasa Internet Indonesia (APJII). (2017). Hasil survey 2016. Retrieved from http//:apjii.or.id/survei2017

Bakardijeva, M. (2003). Virtual Togetherness: An every-day life perspective. Media, Culture and Society, 25(3), 291-313.

Bakti, A. F. (2018). Media and religion: Rodja TV's involvement in the civil society discourse for community development. Jurnal Komunikasi: Malaysian Journal of Communication, 34(3), 226-244.

Barker, E. (2005). Crossing the boundary: New challenges to religious authority and control as a consequences of access to the Internet. In M. Hojsgaard \& $\mathrm{M}$. Warburg (Eds.). Religion and cyberspace. London: Routledge.

Campbell, H. A. (2005). Exploring religious community online. New York: Lang.

Campbell, H. A. (2007). Who's got the power? Religious authority and the Internet. Journal of Computer-Mediated Communication, 12(3).

Campbell, H. A. (2010). When religion meets new media. New York: Routledge.

Campbell, H. A. (2013). Digital religion: Understanding religious practices in new media. New York: Routledge.

Campbell, H. A. (2015). Digital Judaism: Jewish negotiations with digital media and culture. New York: Routledge.

Campbell, H. \& Lovheim, M. (2011). Introduction: Rethinking the online-offline connection

in the study of religion online. Information Communication and Society Journal, 14(8), 1083-1096. Retrieved from https://www.tandfonline.com/doi/abs/10.1080/1369118X.2011.597416

Consalvo, M., \& Ess, C. (2011). The handbook of internet studies. NJ: Wiley-Blackwell.

Creswell, J. W. (2009). Research design: Quantitative, qualitative and mixed methods approaches. California: Sage Publication.

Fukamizu, K. (2007). Internet use among religious followers: Religious postmodernism in Japanese Buddhism. Journal Computer-Mediated Communication, 12(3), 977-998.

Flew, T. (2014). New media. (4th ed.). Australia: Oxford University.

Giddens, A. (1984). The constitution of society. Cambridge: Polity Press.

Guntur, M., \& Tim Majelis Rasulullah. (2013). Habib Munzir: Menanam cinta untuk para kekasih Rasulullah. Jakarta: Qultum Media.

Guzek. D. (2015). Discovering the digital authority: Twitter as reporting tool for papal.

Online-Heidelberg Journal for Religions on the Internet, 9, 63-80. Retrieved from https://heiup.uni-heidelberg.de/journals

Geertz. C. (1996). Religion as cultural system. In Daniel L. P. (Ed), Seven theories of religion. New York: Oxford University Press.

Haythornthwaite, C., \& Wellman, B. (2002). The Internet in everyday life: An introduction. NJ: Blackwell.

Helland, C. (2000). Online-religion/religion online and virtual communities. In J. K. Hadden \& D. E. Cowan (Eds.). Religion on the Internet: Research prospects and promises. New York: JAI Press.

Helland, C. (2005). Online religion as lived religion: Methodological issues in the study of religious participation on the Internet. Online - Heidelberg Journal of Religions on the Internet, 1(1), Special Issue on Theory and Methodology.

Hoover, S. M. (2002). Religion in the media age. New York: Routledge. 
Hookway, J. (2012, October 10). Moderate Islamic preachers gain follower in Indonesia. the Wall Street Journal. Retrieved from: http://www.wsj.com

Katz, R., \& Kahn, R. (1966). The social psychology of organization. NY: Wiley.

Katz, J. E., \& Rice, R. E. (2002). Social consequences of Internet use: Access, involvement, and interaction. Cambridge: MIT Press.

Lincoln, Y. S., \& Guba, E. G. (1982). Epistemological and methodological bases of naturalistic inquiry. Educational Technology Research and Development, 30(4), 233-252.

Littlejohn, S. W. (2002). Theories of human communication. New York: Routledge.

Lister, M. (2009). New media: Critical introduction (2nd ed.). NY: Routledge.

Majelis Rasulullah Website. (2014). Organisasi. Retrieved from http:// www.majelisrasulullah.org

Marcotte, R. D. (2015). Let's talk about sex: Australian Muslim online discussions. Contemporary Islam, 9(1), 65-84. doi: 10.1007/s11562-014-0316-9

Martinez-Zárate, Pablo, Isabela Corduneanu, and Luiz M. Martinez. (2008). S(I)pirituality. Immersive Worlds as a Window to Spirituality Phenomena. Online - Heidelberg Journal of Religions on the Internet, 3. Retrieved from https://archiv.ub.uniheidelberg.de/volltextserver/8295/

McQuail, D. (2010). Mass communication theory (6th ed.). Thousand Oaks: Sage Publication.

Meyrowitz, J. (1985). No sense of place: The impact of electronic media on social behaviour. New York: Oxford university Press.

Mishra, S., \& Semaan, G. (2010). Islam in cyberspace: South Asian Muslims in America log in. Journal of Broadcasting and Electronic Media, 54(1), 87-110.

Pacey, A. (2000). The culture of technology. USA: MIT Press.

Pals, D. L. (1996). Religion as cultural system: Clifford Geertz. Seven theories of religion. NY: Oxford University Press.

Pew Research Centre. (2014). Religion and electronic media. Retrieved from https://www.pewforum.org.2014/11/06/religion-and-electronic-media/

Preston, J. (2011, September 7). Facebook pages for jesus with highly active fans. The New York Times. Retrieved from http://www.nytimes.com

Stout, D. A. (2012). Media and religion. New York: Routledge.

Zimmerman, D., \& Weaver, D. (2008). The Amish and the media. USA: Johns Hopkins University Press. 